\title{
Risk Assessment of Feasibility Study for Toll Road X - Y with Public Private Partnership (PPP) Scheme
}

\author{
H. T. Tjendani ${ }^{1 *}$, R. Marleno ${ }^{2}$, Hendry ${ }^{3}$, I. Subiyantoro ${ }^{4}$. \\ $1^{* 2,4}$ Master of Civil Engineering, Faculty of Engineering, University of 17 Agustus 1945 Surabaya. \\ ${ }^{3}$ Civil Engineering, Faculty of Civil Engineering, University of 17 Agustus 1945 Surabaya.
}

Email:1*hanie_tekitjendani@yahoo.com

\begin{tabular}{|c|c|}
\hline Article History & \\
\hline Article entry & : 16-02-2021 \\
\hline Article revised & : 10-03-2021 \\
\hline Article received & : 17-03-2021 \\
\hline
\end{tabular}

Keywords :

Infrastructure, Public Private Partnership, Risk Assessment, Risk Sharing, Toll Road.

IEEE Style in citing this article: [4] S. Susanto, Hendy, Sumargono, B. Winarno, A. I. Candra, "Measurement of Occupational Safety And Health Risk Levels Of Kadiri University LP3M Building" Ukarst Vol. 4, No. 2, (2020)

\section{Introduction}

Toll road development is expected to provide benefits, including regional development and economic improvement increasing mobility and accessibility of people and goods, saving on vehicle operating costs, and business entities getting investment returns through toll revenues depending on the toll road capacity. However, the development of toll road infrastructure in Indonesia is very slow compared to other countries such as China, Japan, South
The PPP scheme is carried out in Indonesia to procure public infrastructure but is constrained by the government's limited funds. Risk assessment is very important for investors to do to find out the uncertainty that can occur in investing their funds in infrastructure. This study aims to assess the Risk of Feasibility on the X - Y Toll Road, where the location is part of the East Java Province economic development acceleration program by President Regulation number 80 of 2019. The assessment carried out includes risk analysis in the pre-construction, construction, and post-construction stage. The data used are primary data and secondary data. From the assessment results, it was found that most of the assessment points were categorized as medium risk, and there was a little high risk. Still, this project is very profitable because it will be able to synergize with the previously planned infrastructure. The $\mathrm{X}-\mathrm{Y}$ toll road is still possible by paying attention to risk factors and complying with risk mitigation efforts. The toll road procurement scheme with Public-Private Partnership (PPP) already has a robust legal rule and has been guaranteed in terms of security, and this scheme is very potential to be implemented. 
Korea, and Malaysia. Providing very expensive land is often an obstacle in the construction of this toll road because the residents are not willing to negotiate. From 1978 - 2004, all land and infrastructure costs were financed by the government in its history. From 2004 until now, the private sector's role has been urgently needed in the development of public infrastructure [1].

Regulation of the President Republic of Indonesia Number 38 of 2015 concerning Public-Private Partnership in the provision of infrastructure establishes through the consideration that the existence of suitable and sustainable infrastructure is urgent to support the implementation of national development in order to improve the national economy, the prosperity of society, and improve Indonesia's competitiveness in global competition[2]. Towards accelerating infrastructure development, it is necessary to take comprehensive steps to create an investment atmosphere to encourage business entities' participation in the provision of infrastructure and services based on business principles to encourage and enhance collaboration between the government and business entities in the provision of infrastructure. So, it is necessary to regulate and protect the interests of consumers, communities, and business entities in a fair manner. The regulation that the PPP preparation study includes pre-feasibility study activities including preparation of the preliminary feasibility study, consisting of: legal and institutional studies; technical studies; economic and commercial studies; environmental and social studies; study of forms of cooperation in infrastructure provision; risk assessment; assessment of the need for government support and/or Government guarantee; and studies on things that need to be followed up[2].

The plan to develop several toll road sections in East Java with the Public-Private Partnership (PPP) scheme is part of the East Java Province economic development acceleration program in accordance with Presidential Regulation 80 of 2019, regarding the acceleration of economic development in the Gresik-Bangkalan-Mojokerto-Surabaya-Sidoarjo-Lamongan areas, Bromo-Tengger-Semeru areas as well as selingkar Wilis and Lintas Selatan. To support and provide added value to the regional development as previously mentioned, the development of the Ijen Circular Area and the Madura and Archipelago Area was also carried out. This Risk Assessment is part of the Pre-feasibility Study for the X-Y toll roads project in the East Java Region, which will be carried out under the PPP scheme[3]. The investment will always involve risks at a certain scale in the context of construction management. These risks can impact the failure to achieve the objectives (project objectives), such as budget costs and implementation time so that a risk analysis is necessary. As an example of the Pekanbaru-Dumai toll road project, the most sensitive risk factors for toll road construction are land availability, 
compensation processes, community refusal, the number of land brokers, and unsustainable funding sources that risk mitigation can be focused on these five parameters [4].

\section{Literature Review}

Risk is an uncertain condition or event that has a positive or negative effect on the project objectives if it occurs. A risk has a cause, and if that risk occurs, there are consequences. If what happens is an uncertain event, then the impact will be on the project's cost, schedule, and quality. Meanwhile, risk management is an art and science in identifying, analyzing, and responding to risk factors that exist during the implementation of a project [5]

Project Risk Management is a systematic process for planning, identifying, analyzing, planning risk response, monitoring, and risk control. Project Risk Management aims to increase knowledge about the probability of positive events and reduce the likelihood \& impact of negative case records in the project. Each project has a diverse risk identification and risk response to minimize the impact of the risks. Risks can have an indirect impact on the project implementation schedule. Risk categories in construction projects are external risk, economic $\&$ financial risk, technical \& contract risk, and managerial risk. It is important to identify risks correctly and allocate these risks into agreement/contract effectively [6]. Risk leads to the uncertainty of an event's occurrence during a specific period that causes losses, be it small or significant losses, which affect the profitability of a company[7].

The appropriate risk management must apply the possibilities in the future and be proactive rather than reactive. In this case, risk management reduces the likelihood of risk and the impact of the risks. The stages of risk management presented in an overview of Figure 1 below :

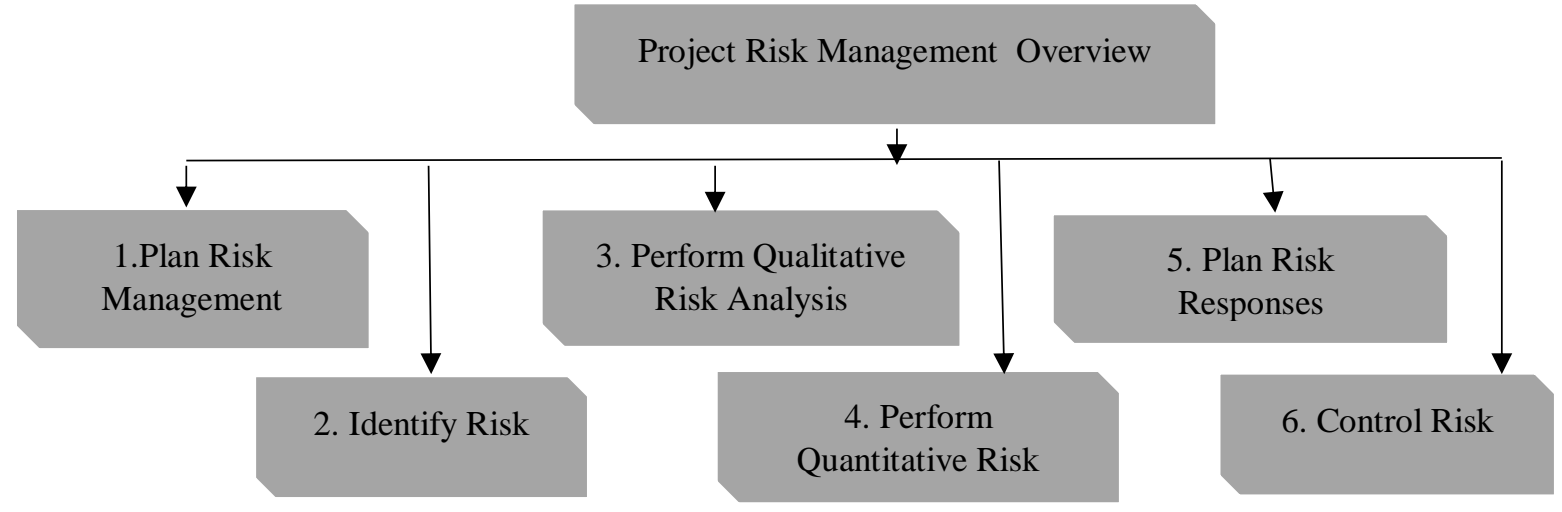

Figure 1. Project Risk Management Overview

Source : PMI, 2013 
Figure 1. Explains the steps in project risk management with the following description [8]:

1) Plan Risk Management is a process of defining risk management activities for a project;

2) Identify Risks is the process of determining the risks that can affect the project and noting the characteristics of each risk;

3) Perform Qualitative Risk Analysis is the process of prioritizing risks for further analysis or action by assessing and combining the likelihood of risk impacts occurring;

4) Perform Quantitative Risk analysis is a numerical process of analyzing the effect of identified risks on the overall project objectives;

5) Plan Risk Responses is the process of developing options and actions to increase opportunities and reduce threats to project objectives;

6) Control Risk is the process of implementing a risk response plan, tracking identified risks, monitoring residual risks, identifying new risks, and evaluating the effectiveness of risk processes throughout the project.

\subsection{Risk Transfer}

Risk transfer is a shift in some or all of the threats/hazards, negative impacts, and consequences to third parties. Transfer of risk only assigns management responsibility to another party without eliminating the responsibility itself. Transfer of Risk almost always involves the payment of a risk premium to the party taking the risk. Transfers can be very diverse and include (but are not limited) to use of insurance, performance bonds, guarantees, and others. A contract can be used to transfer responsibility for certain risks to other parties [9].

A risk-sharing and transfer mechanism has been tried as a pilot project and is widely using in mega construction projects. Contractual relationships and integrated project organization are two methods commonly used to reduce risk across stakeholders and how the structure of alliance government in the construction sector can balance control and trust in dealing with risks empirically explored the effects of cooperative procurement on risk management in construction projects [10]. Academics and practitioners are also encouraged to reflect more on "how to combine" different management systems to achieve successful cooperative risk management[11]. Risk can also define as the implication of uncertainty that could potentially affect project objectives, either positively or negatively. The opposite of the hypothesis is that different stakeholders will prioritize different sources of risk[12].

Toll roads are the infrastructure of construction projects that often involve many different roles with various features [13]. Toll road projects require a more complex 
organizational structure that deals with some elements and risk management. General risk management elements in toll road projects can be a multi-layer relationship where there are multiple stakeholders in the toll road project, all with different objectives. There is a need to manage relationships among stakeholders effectively. The partnerships between stakeholders in a project are aligned to achieve the best results for all [14]. The risk of conflict and interaction related to human relations can use as a structure for project governance. Understanding rationality and moral hazard must be well understood, predictable, and planned and good communication on risk-sharing [15]. Risk management is cost, time, and safety in several cases in infrastructure development projects, including toll roads. There are delays and budget overruns due to unique circumstances[16], hidden transaction costs, or disputes between parties [17]. There is the involvement of many workers in toll road projects, environmental factors with heavy terrain, several heavy materials and equipment, complex construction operations, multiinterface, and complex management activities[18].

\subsection{Risk Management on The Toll Road Project}

Investors in toll road infrastructure always consider the following aspects: fairness, justice, economy, and the environment. The fairness aspect: the level of investment risk based on assumptions about normal conditions and general in the context and practice of business in Indonesia, if it occurs outside the usual and capability of the parties involved to deal with it will be considered a force majeure event. The justice aspect: the risk assessment must consider the political, social, and economic conditions of the parties involved. Risk assignment base on the principle that risk is assigned to the party best able to manage, control, and reduce the level of risk. The economic aspect: the estimated risk value must calculate in determining the feasibility of both a business economically and financially. The risk management effort must carry out by considering generally accepted economic instruments and following the existing laws and regulations. The environmental aspects: the neighborhood impact of the proposed activity/project must calculate as economic cost or surroundings cost of the project and not a business risk. The Risks category into two types, namely: speculative risk, especially risks that, besides containing potential losses, the activities carried out also include potential benefits such as those who invest in the stock exchange; and, pure risk, this risk only has a probability loss as well as an accident risk [19].

Through The Indonesian Infrastructure Guarantee, the government is expected to assure investors that the investment capital for the $\mathrm{X}-\mathrm{Y}$ toll road will return. PPP is a form of risk 
response, specifically risk-sharing between the government and business entities (private sector)[20].

\subsubsection{Toll Road Risk Category \& Element}

In toll road investment, there are risk categories that must consider, specifically [21]: Project performance risk consists of Planning risk, especially the risk that occurs at the planning stage such as competition, namely the risk that other development alternatives provide more attractive options than the existing proposal, the risk of sudden change or relocation of a potential target location which results in a decrease in the feasibility of the project to be developed, the sponsors (investors) involved in the project fail to fulfill their obligations, the risk where a project that was initially thought to be feasible turns out to be unsatisfied with several assumptions so that it is not feasible and must be canceled. Implementation risk, namely the risk that occurs during the implementation of work (development) such as cost escalation (cost overrun), namely the risk in which the agreed construction budget for project implementation is insufficient, causing additional costs during implementation. These additional costs may result from price increases, inadequate project design, delays, or other unexpected events. The risk that the estimated time to carry out the work is insufficient, resulting in delays. The project's risk fails to obtain permits, licenses, and government approvals according to the targets set so that the project can be implemented. Licensing failure can be caused by various things such as inappropriate design, environmental impact, community refusal, and complicated licensing procedures. The risk that the technology used does not work as expected. This is due to the desire of certain parties to require cutting-edge technology whose reliability has not been tested. The risk that the resulting technical design is less than perfect so that it does not meet the required specifications. This risk can lead to delays, additional costs, decreased performance, increased operating costs, or reduced design life.

An operational risk that occurs during operations such as operating costs that the budgeted operating costs are not sufficient, causing additional costs. This could result from increased costs being unclear, e.g management, project design errors, or other unforeseen reasons. The risk where the project operator fails to fulfill its obligations according to the agreed targets and conditions. Operator performance failure can be in the form of failure to deliver technical services, strike, or failure in financing. The risk that the supply of project operation needs is not sufficiently available, does not meet specifications, or experiences price increases that affect the project's financial condition. The risks associated with the issue of licensing 
renewal, license, or approval required for the activity to continue operating. The technology risk can occur as implementing the risk that the technology was chosen or used does not work as expected. The design risk, such as in the implementation stage this risk is caused by design imperfections which result in not being able to meet the expected performance, result in an increase in operating costs. The environmental risk, a risk arising from the impact of the project's existence on the environment both in the short and long term. This risk can be in the form of additional costs to restore environmental conditions or costs to construct additional facilities to compensate for existing environmental impacts.

\subsubsection{Policy Risk Analysis}

Governance risks (including legal and regulatory risks) include political, laws and regulations, and foreign exchange. The political risk especially convertibility the risk due to political instability such as uncertainty in security guarantees, economic stability, and unclear government policies. Laws and regulations are the risks due to changes in laws and regulations such as changes in laws and regulations, including policies that can affect project feasibility. Foreign exchange convertibility is the risk that local currency cannot be exchanged for foreign currency for debt payments, causing failure to fulfill payment obligations. The risk of force majeure consists of: natural disasters, specifically risk caused by natural disasters such as earthquakes, floods, volcanic eruptions, storms, etc. which has an impact on ongoing projects; political force majeure, namely the risk of political rebellion, can impact project operations and financial conditions. Included in this category are risks resulting from war, rebellion, revolution, terrorism, mass strikes, public security disturbances, etc.[20]

The risk element is part of a series of project implementation activities/activity plans that have potential cause risks. The grouping risk elements of the investment toll road divided into three stages consist of the Pre-Construction Stage, the Construction Stage, and the PostConstruction Stage. From these stages, several events could potentially pose a risk. In general, the phase, definitions, and events can prepare as risk identification in toll road investment.

\subsubsection{Territory Risk Analysis}

Physiologically and geographically, the East Java region is generally grouped into three zones, namely: the southern zone (plateau), the middle zone (volcanoes), and the northern zone (folds). In the middle lies a series of volcanic mountains (19 mountains, Mount Kelud, Mount Bromo, and Mount Semeru). Gunung Kelud is included in the area of the Kediri Regency. 
In the southern part, there is a series of hills, namely from the southern coast of Pacitan, Trenggalek, Tulungagung, Blitar, to Malang. The South Cretaceous Mountains are a continuation of the Sewu Mountains in Yogyakarta. The two most important rivers in East Java are the Brantas River, which crosses Kediri and Bengawan Solo's districts. In an area with a population density of up to 772 people per square $\mathrm{km}$, many industries and mining (minerals, minerals, and oil and gas) are developed. Of the 38 districts/cities in East Java Province, 30 of them are in the high-risk class. Based on the Threat, Vulnerability and Risk Analysis for the Hydrometeorological Disaster Management Sector, the 2018 East Java Vulnerability Assessment Report can guide regional risk analysis[22].

\section{Research Method}

This research was done on Toll Road X-Y with PPP scheme, one of the Presiden Republik Indonesia regulation number locations. 80, 2019 concerning the acceleration of economic development The Gresik-Bangkalan-Mojokerto-Surabaya-Sidoarjo-Lamongan area, the Bromo-Tengger-Semeru area, as well as the Selingkar Wilis and Lintas Selatan areas. This study uses primary data and secondary data. Primary data as preliminary data carry out by distributing questionnaires to respondents to obtain the probability and impact of risks in the toll road planning in one of the toll road sections in East Java. Meanwhile, secondary data from several regulations in the ministry of public works, the center for research and development of transportation infrastructure, the Regional Development Planning Agency of East Java Province, and the journals, both national and international journals.

The risk level analysis on the equation of investment risk factors, where the magnitude of the risk factors is a description of the level of investment risk that occurs. The risk factor equations defined as the multiplication of the impact magnitude and the risk event probability, which is calculated from the following equation, specifically[4]:

$\mathrm{FR}=\mathrm{L}+\mathrm{I}-(\mathrm{L} \times \mathrm{I})$

with description:

FR = Risk factors, on a scale of $0-1$

$\mathrm{L}=$ The probability of a risk event,

I = Magnitude of the impact risk in the form of increased costs.

If the actual probability value not available, a typical risk event probability value can use for the risk analysis of toll road investment, as stated in the Construction and Building Guidelines Pd T-01-2005-B concerning the Investment Risk Analysis of the Department of Public Works 
Toll Road. Meanwhile, to estimate the magnitude of the impact due to toll road investment risk, a typical value (default) can use as stated in the same Construction and Building Guidelines.

Table 1. Risk Categorization

\begin{tabular}{|c|c|c|}
\hline Risk Factor Value & Category & Handling Step \\
\hline 20 & 12 & $\begin{array}{l}\text { It must do to reduce the risk } \\
\text { become to the lower-level } 20\end{array}$ \\
\hline 40 & 15 & $\begin{array}{l}\text { Corrective steps needed within a } \\
\text { fixed period } 30\end{array}$ \\
\hline 60 & 20 & $\begin{array}{l}\text { Remedial steps whenever } \\
\text { possible }\end{array}$ \\
\hline
\end{tabular}

Sources: A. Sandhiavitri et al, 2019 [4].

Data processing for survey results to respondents in the form of probability and impact risks for toll road investment is carried out on a Likert scale followed by calculating risk factors according to formula (1). After obtaining the risk factors, the risk category can be determined according to Table 1. Furthermore, the risk matrix shown in Figure 1, can use graphically illustrate the existing risk category.

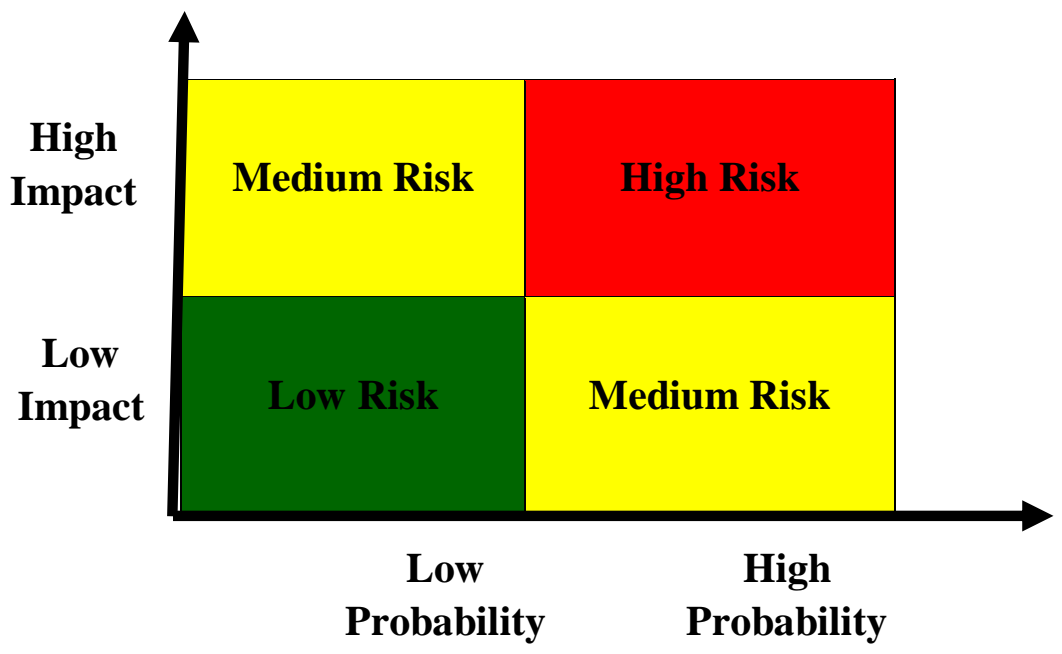

Sources : A. Sandhiavitri et al, 2019

Figure 2. Matrix of Risk Categorization

\section{Results and Discussions}

\subsection{Risk Probability And Risk Impact}

Risk impact assessment is needed to assess the likelihood and consequences of risk events. This assessment is the beginning of the pre-construction process. The preliminary survey regarding the possibility and impact of risks on the X-Y Toll obtained the following results: 
Table 2. Probability Average in Preliminary Survey and Probability-Based on PU Research Center Guidelines [23]

\begin{tabular}{lcc}
\hline \multirow{2}{*}{ Risk Factor Value } & \multicolumn{2}{c}{ Probability Average } \\
\cline { 2 - 3 } & $\begin{array}{c}\text { Preliminary } \\
\text { Survey }\end{array}$ & $\begin{array}{c}\text { Based on } \\
\text { Pd-T-01-2005 }\end{array}$ \\
\hline Permit and Licences & 0.275 & 0.668 \\
Tender Process & 0.256 & 0.670 \\
Contract Document & 0.432 & 0.705 \\
Study & 0.453 & 0.663 \\
Data Used & 0.524 & 0.679 \\
Assumption Taken & 0.458 & 0.667 \\
Design & 0.398 & 0.488 \\
Standard & 0.337 & 0.521 \\
Mis Interpretation & 0.326 & 0.502 \\
Land Acquisition & 0.681 & 0.838 \\
Availability of Land & 0.395 & 0.637 \\
Compensation Process & 0.714 & 0.830 \\
Public Repudiation & 0.452 & 0.777 \\
Many brokerages & 0.685 & 0.809 \\
Investation & 0.250 & NA \\
Sources of funding & 0.347 & NA \\
Continuity of Fund Sources & 0.312 & NA \\
Loan Repayment Period & 0.548 & NA \\
\hline
\end{tabular}

Sources: Analysis Results, 2020

Risk analysis is categorizing risks into several categories as well as listed in Table 2 and Figure 1, where: Low risk is a risk that can be accepted or ignored; The moderate risk is the risk that has a high level of likelihood but a low impact or a low probability level but a high impact; High risk is a risk that has a high probability of occurrence and a great deal of an impact [4].

Table 3. Preliminary Survey Risk Impact and Risk Impact based on the PU Research Center Guidelines

\begin{tabular}{lcc}
\hline \multirow{2}{*}{ Risk Factor Value } & \multicolumn{2}{c}{ Probability Average } \\
\cline { 2 - 3 } & Preliminary & Based on \\
& Survey & 0,11736 \\
\hline Permit and Licences & 0,2625 & 0,17778 \\
Tender Process & 0,252777778 & 0,18819 \\
Contract Document & 0,230555556 & 0,10139 \\
Study & 0,159027778 & 0,16389 \\
Data Used & 0,220138889 & 0,17292 \\
Assumption Taken & 0,182638889 & 0,16736 \\
Design & 0,452083333 &
\end{tabular}




\begin{tabular}{lcc}
\hline \multirow{2}{*}{ Risk Factor Value } & \multicolumn{2}{c}{ Probability Average } \\
\cline { 2 - 3 } & $\begin{array}{c}\text { Preliminary } \\
\text { Survey }\end{array}$ & Based on \\
& 0,384722222 & 0,32708 \\
\hline Standard & 0,445833333 & 0,31181 \\
Mis Interpretation & 0,326388889 & 0,32014 \\
Land Acquisition & 0,484027778 & 0,30833 \\
Availability of Land & 0,313194444 & NA \\
Compensation Process & 0,361805556 & NA \\
Public Repudiation & 0,354166667 & NA \\
Many brokerages & 0,29375 & NA \\
Investation & 0,240972222 & NA \\
Sources of funding & 0,216666667 & NA \\
Continuity of Fund Sources & 0,380555556 & NA \\
Loan Repayment Period & & \\
\hline
\end{tabular}

Sources: Analysis Results, 2020.

Table 3 shows, the pre-construction risk probability on the X-Y toll road project is smaller than the pre-construction risk probability in Indonesia according to the construction and building guidelines for investment risk analysis from the Ministry of Public Works Research and Development Center. It shows that the communities around X-Y support infrastructure development in this area and support local investors with international investment standards that the risk probability shows the lowest number.

\subsection{Risk Category}

Following are the results of risk factor measurement and risk categorization in the preconstruction stage on the $\mathrm{X}-\mathrm{Y}$ toll road.

Table 4. Risk Factors for Pre-Construction of the X-Y Toll Road

Pre-Construction

\section{Permit and Licences}

a. Tender Process

b. Contract Document

\section{Study}

a. Data Used

b. Assumption Taken

3. Design

a. Standard

b. Mis-Interpretation

\section{Probability Impact}

(L)

(I)
$\mathbf{F R}=\mathbf{L}+\mathbf{I}-(\mathbf{L} * \mathbf{I}) \quad$ Risk Category

$\begin{array}{llll}0.275 & 0.213 & 0.429 & \text { Medium Risk } \\ 0.256 & 0.220 & 0.420 & \text { Medium Risk } \\ 0.432 & 0.354 & 0.633 & \text { Medium Risk } \\ 0.453 & 0.378 & 0.660 & \text { Medium Risk } \\ 0.524 & 0.364 & 0.697 & \text { Medium Risk } \\ 0.458 & 0.332 & 0.638 & \text { Medium Risk } \\ 0.398 & 0.226 & 0.536 & \text { Medium Risk } \\ 0.337 & 0.317 & 0.547 & \text { Medium Risk } \\ 0.326 & 0.263 & 0.503 & \text { Medium Risk }\end{array}$




\section{Pre-Construction}

\section{Land Acquisition}

a. Availability of Land

b. Compensation Process

d. Public Repudiation

e. Many brokerages

\section{Probability Impact}

(L)

(I)

$\begin{array}{llll}0.681 & 0.651 & 0.889 & \text { Medium Risk } \\ 0.395 & 0.554 & 0.730 & \text { Medium Risk } \\ 0.714 & 0.642 & 0.898 & \text { High Risk } \\ 0.452 & 0.470 & 0.710 & \text { High Risk } \\ 0.685 & 0.697 & 0.905 & \text { High Risk }\end{array}$

FR=L+I-(L*I) Risk Category

High Risk

Sources: Analysis Results, 2020.

Based on Table 4, it can see that the risk impact of the pre-construction stage on the $\mathrm{X}-\mathrm{Y}$ toll road is greater than the typical value of the toll road investment risk, which comes from the Toll Road Risk Analysis Guidelines from The Ministry of Public Works Research and Development Center especially on the risk elements of land acquisition and investment. This phenomenon could have occurred because the $\mathrm{X}-\mathrm{Y}$ area people already know that their area is one of the strategic infrastructure development areas. Land acquisition will demand high compensation prices and emerge intermediaries who take advantage of this condition for personal or group interests.

Risk analysis performs using the investment risk factor (FR) equation. The amount of the FR shows the level of investment risk that occurs. FR is defined as the multiplication of the impact magnitude and the risk event probability, according to equation 1, in the investment risk analysis. The next step is to categorize risks into several categories as listed in Table 4 where: Low risk is a risk that can be accepted or neglected; Medium risk, namely the risk with a high probability level but the low impact or a low probability level but high impact; High risk, is a risk that has a high probability of occurrence and a large impact.

\subsection{Risk Allocations}

Based on the toll road risk analysis guidelines, there is an allocation of risk between the government and the private sector:

Table 5. Risk allocation on the Pre-Construction Stage

\begin{tabular}{llcc}
\hline \multirow{2}{*}{ Risk Element } & \multicolumn{2}{c}{ Risk Allocation } \\
\cline { 3 - 4 } & & Government & Private Sector \\
\hline Permit and Licences & Tender Process & $84 \%$ & $16 \%$ \\
Study & Contract Document & $45 \%$ & $55 \%$ \\
& Data Used & $64 \%$ & $36 \%$ \\
Design & Assumption Taken & $56 \%$ & $44 \%$ \\
\hline
\end{tabular}

Risk Assessment of Feasibility Study for Toll Road X - Y with Public Private Partnership (PPP) Scheme 


\begin{tabular}{llcc}
\hline & \multirow{2}{*}{ Risk Element } & \multicolumn{2}{c}{ Risk Allocation } \\
\cline { 3 - 4 } Land Acquisition & Government & Private Sector \\
& Standard & $48 \%$ & $52 \%$ \\
& Mis Interpretation & $36 \%$ & $64 \%$ \\
& Availability of Land & $80 \%$ & $20 \%$ \\
Investation & Compensation Process & $77 \%$ & $23 \%$ \\
& Public Repudiation & $81 \%$ & $19 \%$ \\
& Many brokerages & $74 \%$ & $26 \%$ \\
& Sources of funding & $65 \%$ & $35 \%$ \\
& Continuity of Fund Sources & $65 \%$ & $35 \%$ \\
& Loan Repayment Period & $65 \%$ & $35 \%$ \\
\hline
\end{tabular}

Sources: Pd-T-01-2005B [18]

The allocations of risk are based on the government's respective burdens and responsibilities and the private sector. With the same method, analysis is carried out at the Construction and Post-Construction stages.

\section{Conclusion and Suggestion}

\subsection{Conclusion}

Based on the results of the analysis and secondary data: [18]; [20], the preparation of the X-Y Toll Road project risk assessment can be stated that: the results of risk analysis on the planning of the construction of the X-Y toll road from an investment perspective show that this project very profitable because it will be able to synergize with the previously planned infrastructure supported by investors with very strong funding. In the pre-construction stage, the Risk Factor (FR) in the High Category on the elements of land availability, the compensation process, and concerns about the number of brokers/land brokers. At the construction stage, the high FR category includes weather conditions, inflation, capital returns, and government policies changes. Meanwhile, in the post-construction stage, the FR in the High category occurs in the inflation element during the operational and maintenance period, the increase in bank exchange rates/interest, the determination of the initial rate \& tariff adjustments, and changes in government policies/state conditions.

The PPP scheme for toll roads has long been implemented in Indonesia, but the long duration phase must be examined in detail to produce more accurate risk mitigation at each stage. Based on the discussions that have been presented and the matrix of risk allocation and risk mitigation from the results of this study. The $\mathrm{X}-\mathrm{Y}$ Toll Project is recommended to be implemented. 


\subsection{Suggestion}

For further research, it is advisable to include the budget by investors to calculate investment risk and analyze the environment and policy.

\section{Acknowledgment}

Researchers would like to greatly appreciate the Universitas 17 Agustus 1945 Surabaya and PT (Persero) Virama Karya, East Java Branch.

\section{References}

[1] Latif Adam, Analisis Model Kebijakan Kerja Sama Pemerintah Swasta Dalam Pembangunan Infrastruktur. LIPI Press, ISBN 9789797997724, 2014.

[2] Presiden Republik Indonesia, "PERPRES No. 38 Tahun 2015 tentang Kerjasama Pemerintah dengan Badan Usaha dalam Penyediaan Infrastruktur [JDIH BPK RI], 2015. https://peraturan.bpk.go.id/Home/Details/41764/perpres-no-38-tahun-2015 (accessed Jan. 20, 2021).

[3] Presiden Republik Indonesia, "PERPRES No. 80 Tahun 2019 tentang Percepatan Pembangunan Ekonomi di Kawasan Gresik - Bangkalan - Mojokerto - Surabaya Sidoarjo - Lamongan, Kawasan Bromo - Tengger - Semeru, serta Kawasan Selingkar Wilis dan Lintas Selatan [JDIH BPK RI], 2019. https://peraturan.bpk.go.id/Home/Details/126140/perpres-no-80-tahun-2019 (accessed Jan. 20, 2021).

[4] A. Sandhyavitri and N. Saputra, "Analisis Risiko Jalan Tol Tahap Pra Konstruksi (Studi Kasus Jalan Tol Pekan Baru-Dumai),” J. Tek. Sipil, vol. 9, no. 1, pp. 1-19, 2019, doi: 10.28932/jts.v9i1.1366.

[5] H. Pertiwi, "Implementasi Manajemen Risiko Berdasarkan PMBOK Untuk Mencegah Keterlambatan Proyek Area Jawa Timur (Studi Kasus: PT. Telkom)No Title,” J. Stud. Manaj. dan Bisnis, vol. 4, no. 2017/12/24, pp. 96-108, 2017, doi: 10.21107/jsmb.v4i2.3959.

[6] N. A. and I. P. A. W. Hanie Teki Tjendani, "ARPN JEAS 2018." ARPN Journal of Engineering and Applied Sciences @2006-2018 Asian Research Publishing Network (ARPN). All rights reserved., pp. 4432-4439, 2018, [Online]. Available: http://www.arpnjournals.com/jeas/volume_15_2018.htm. 
[7] S. Susanto, H. Hendy, B. Winarno, and A. I. Candra, "Measurement Of Occupational Safety And Health Risk Levels Of Kadiri University LP3M Building," UKaRsT, vol. 4, no. 2, p. 124, Oct. 2020, doi: 10.30737/ukarst.v4i2.782.

[8] A Guide to the Project Management Body of Knowledge. 2013.

[9] F. Guo, Y. Chang-Richards, S. Wilkinson, and T. C. Li, "Effects of project governance structures on the management of risks in major infrastructure projects: A comparative analysis," Int. J. Proj. Manag., vol. 32, no. 5, pp. 815-826, 2014, doi: 10.1016/j.ijproman.2013.10.001.

[10] E. Osipova and P. E. Eriksson, "Balancing control and $\mathrm{fl}$ exibility in joint risk management : Lessons learned from two construction projects," pp. 9-11, 2012.

[11] A. Darda, M. Miki, I. Kova, and Z. Ceki, "Global Perception of Sustainable Construction Project Risks," vol. 119, no. Williams 1995, pp. 456-465, 2014, doi: 10.1016/j.sbspro.2014.03.051.

[12] A. Shiferaw, E. Siba, and G. Alemu, "Road Infrastructure and Enterprise Development in Ethiopia," no. September, 2012.

[13] H. V. Rick Janssen, Robin de Graaf, Marnix Smit, "Why local governments rarely use PPPs in their road development projects: Understanding the barriersNo Title," Int. J. Manag. Proj. Bus., vol. Vol. 9 No., no. 01/04/2016, pp. 33-52, 2016, [Online]. Available: https://www.emerald.com/insight/content/doi/10.1108/IJMPB-06-2015-0043/full/html.

[14] Y. Ke, S. Wang, and A. P. C. Chan, "RISK MANAGEMENT PRACTICE IN CHINA' S PUBLIC-PRIVATE," vol. 18, no. 5, pp. 675-684, 2012, doi: $10.3846 / 13923730.2012 .723380$.

[15] M. Waris, Asadullah Khan, I. Ismail, and S. Panda, "PROJECT GOVERNANCE: A NEED FOR PUBLIC SECTOR INFRASTRUCTURE PROJECTS IN PAKISTAN No Title," FGIC 1st Conf. Gov. Integrity, 2017, vol. 1, pp. 141-154, 2017, doi: ISBN 978967-2054-37-5.

[16] K. Sha, "Vertical governance of construction projects: An information cost perspective," Constr. Manag. Econ., vol. 29, no. 11, pp. 1137-1147, 2011, doi: 10.1080/01446193.2011.637939.

[17] S. O. O. S. u R Toor, "NBeyond the 'iron triangle': Stakeholder perception of key performance indicators (KPIs) for large-scale public sector development projectso Title," JournalInternational J. Proj. Manag., vol. 28, no. April 2010, pp. 228-236, 2010, doi: doi.org/10.1016/j.ijproman.2009.05.005. 
[18] F. Mallard and D. Franc, "Land Use Policy Effectiveness of the legal framework for natural areas protection relative to French road projects," vol. 30, pp. 2012-2014, 2013.

[19] M. AU - Murphy, G. AU - Heaney, and S. AU - Perera, “A methodology for evaluating construction innovation constraints through project stakeholder competencies and FMEA," Constr. Innov. Information, Process. Manag., vol. 11, no. 2011/10/11, pp. 416440, 2011, doi: 10.1108/14714171111175891.

[20] PT Penjaminan Infrastruktur Indonesia, “Acuan Alokasi Risiko KPBU Di Indonesia,” in Acuan Alokasi Risiko, 2016th ed., Kementerian Keuangan, 2016.

[21] Kementerian Pekerjaan Umum dan Perumahan Rakyat Republik Indonesia, "Pd T-012005-B tentang Analisis Risiko investasi Jalan Tol,” 2005.

[22] DAI, “LAPORAN KAJIAN KERENTANAN DAN RISIKO IKLIM PROVINSI JAWA TIMUR No Title," in LAPORAN KAJIAN KERENTANAN DAN RISIKO IKLIM PROVINSI JAWA TIMUR, Surabaya: USAID/Indonesia Office of Environment, 2018.

[23] A. Sandhyavitri and N. Saputra, “( Studi Kasus Jalan Tol Pekanbaru-Dumai ),” Tek. Sipil Maramatha, vol. 1, no. 2, pp. 1-12, 2015. 